\title{
Corruption and Economic Growth: Evidence from Egypt
}

\author{
Tarek Ghalwash \\ Department of Economics, Mansoura University, Mansoura, Egypt \\ Email: tarek.ghalwash@gmail.com
}

Received 29 June 2014; revised 26 July 2014; accepted 28 August 2014

Copyright (C) 2014 by author and Scientific Research Publishing Inc.

This work is licensed under the Creative Commons Attribution International License (CC BY). http://creativecommons.org/licenses/by/4.0/

c) (i) Open Access

\begin{abstract}
Based on a theoretical consideration of economic growth model, this study empirically investigates the direct and indirect impact of corruption on economic growth by incorporating the corruption index in the growth model in the case of Egypt. The model provides a simple theoretical framework in which the level of corruption as well as the effects of corruption on output variables; forging direct investments, government expenditure, openness and political instability are identified. Our main result provides empirical evidence suggesting that corruption increases inefficiencies in government expenditure and reduces investment and human capital, leading to a negative impact on output. In addition, the human capital, openness and political instability are the most important channel variables, through which corruption is likely to reduce growth.
\end{abstract}

\section{Keywords}

\section{Corruption, Development, Governance, Economic Growth}

\section{Introduction}

Over the past years, the question of the economic consequences of corruption on economic growth has long been a subject of analysis and debate. The analysis and debate are essentially focused on the effect of corruption on economic growth. In previous literature, several studies have generally found a negative relation between corruption on one hand and investment and growth on the other hand [1]-[3]. Currently, different organizations view corruption as a major obstacle to good policy making [4]. Other papers claim that if corruption is likely to affect economic growth, its effect would be transmitted indirectly via its impacts on the standard determinants of economic growth. This fact was reinforced by the results of a number of studies that explicitly argued that the total effect of corruption on economic growth could be decomposed into a direct impact and a set of indirect effects manifested by a number of transmission variables [5]-[7]. 
Corruption can affect economy on different ways, and it is important to understand the range and diversity of the mechanisms involved. There is a wide consensus among economists that corruption distorts relative prices, discourages savings and investment, and hinders economic growth and development [8] [9]. Despite a considerable number of theoretical and empirical studies, there is still no agreement on the different ways in which corruption might affect economic growth.

[10] studied the impact of corruption on economic growth and argued that corruption distorts incentives and encourages talented people to engage in more profitable rent-seeking activities instead of socially productive activities. The diversion of talent from productive to rent-seeking activities (i.e. extracting bribes) will hamper economic growth. On the other hand, some studies claim that corruption in an economy acts like a grabbing hand that increases the costs of carrying out business activities and therefore increase the costs of foreign investments and will, therefore, discourage FDI for both developed and developing countries [11]-[17]. [18] [19] examined the impact of corruption on human development and found that corruption might compromise human development through a deterioration in the scale of public health and education programs. Others argued that corruption might lead to a general misallocation of public expenditures as certain areas of spending (military spending) were targeted more for their capacity to generate bribes than their potential to improve living standards [20] [21]. Furthermore, other authors including [22] [23] have provided similar evidence and reported that the relationship between corruption and economic growth became statistically insignificant after controlling for other important determinants of growth, such as investments, human capital, openness and political instability.

The main conclusion that can be derived from the above studies is that the relation between corruption and economic growth is empirically very ambiguous. Some studies find a significant negative effect of corruption on growth; others show that the effect is statistically insignificant, while others show the effect to be heterogeneous across countries with different institutional frameworks. This means that corruption is deleterious for economic growth but the exact channels through which it affects economic growth are not resolved empirically. Based on the main propositions of previous literature, we develop a new analytical framework to investigate the relation between corruption and economic growth in Egypt and also highlight the mechanisms through which corruption could affect growth. The channels under consideration include foreign direct investment, government expenditure, human capital, openness, and political instability.

To our knowledge, there were few earlier studies examined the effect of corruption on economic growth in Egypt. None of these papers used any econometric analysis to evaluate the effect of corruption on the economic growth either in direct or indirect way. The main objective of this paper, therefore, is to analyze and estimate the effect of corruption on economic growth by performing an econometric analysis with reference to the Egyptian economy. The paper emphasises three questions: First, does corruption affect economic growth in Egypt? Second, is there evidence of a negative correlation between corruption and economic growth? And third, what are the main channels through which corruption affects economic growth?

In order to answer previous questions, this study quantifies both direct and indirect effect of corruption on economic growth and also augments the prior literature by three ways: first, this study is an original effort using time series analysis of data in Egypt over the period of 1990-2012. Second, Unit Root Test is used to test the order of integration of the variables in the presence of structural breaks. Finally, the GMM estimation approach is also applied to detect the direct and indirect relation between corruption and economic growth.

The remainder of this study is presented as follows. Section 2 presents the basic model, the data, and variables. Section 3 presents the results. Section 4 offers some concluding remarks.

\section{Model Specification}

\subsection{Basic Model}

In our framework for investigating the growth mechanism, imagine an economy that produces only one good and the population is constant, for simplicity normalized in size to one. Output is produced with a well-behaved neoclassical production function with positive and strictly diminishing marginal product of physical capital. We assume output depends upon the capital stock $\left(k_{t}\right)$ and human capital a $\left(l_{t}\right)$, which are paid their marginal products. The production function is:

$$
Y=K_{t}^{\alpha} H_{t}^{\beta}\left(L_{t}\right)^{1-\alpha-\beta}, \quad 0 \prec \alpha \prec 1,
$$

where $Y$ is output, $K$ capital, $L$ labor, and $H$ the level of human capital. $H$ and $L$ are assumed grow 
exogenously at rate $g$ and $n$. The model yields standard neoclassical results. That is, the growth rate of output per capita is accelerated with increases in investments in physical capital and decreases in population growth, depreciation rate of capital, and the initial level of output per capita. Following the Solow, the expected steady state of capital-labor ratio is governed by

$$
k^{*}=[s /(n+g+\delta)]^{1 /(1-\alpha)}
$$

where $s$ denotes the propensity to save and $\delta$ the rate of deprecation of physical capital. Equation (2) yields the steady-state capital-labor ratio is related positively to the rate of saving and negatively to the rate of population growth. To get the growth of output per capita at the steady state level, substituting Equation (2) into the production function and taking the $\log$ and differentiating with respect to the time, yields:

$$
\ln y_{t}-\ln y_{0}=\ln H_{t}+g_{t}+(\alpha /(1-\alpha)) \ln s_{t}-(\alpha-(1-\alpha)) \ln (\alpha+g+\delta)
$$

Equation (3) is what the Romer and Weil [24], the standard neoclassical results. That is, the growth rate of output per capita is accelerated with increases in investments in physical and human capital and decreases in population growth, depreciation rate of capital, and initial level of output per capita.

\subsection{The Government}

In this section, we model the effects of government expenditure on growth function as a part of the aggregate economy. Denote total government expenditure by $G_{t}$ and corruption by $\phi$. We can specify the government expenditure function in term of corruption as following:

$$
G_{t}(\phi)=G_{t} \mathrm{e}^{-\gamma \phi} \quad \text { where } \quad 0 \leq \phi \leq 1
$$

Equation (4) show that $\phi$ is the index of corruption in this model, and $\gamma$ determines the magnitude of the effect of corruption on government expenditure. Following the [25] we consolidate the expenditure function in the production function. And assume that the government expenditure is exogenous variable. The production function is

$$
Y=K_{t}^{\alpha} H_{t}^{\beta}\left(G_{t}((\phi)) L_{t}\right)^{1-\alpha-\beta}, \quad 0 \prec \alpha \prec 1,
$$

Equation (5) can be interpreted in two different ways. The first one is the effect of changes in factor availability, the growth component, which is related to the growth rates of capital and labor in the production function. Another is the effect of social and technological changes, the development component, which is related to the forces driving total factor productivity growth in the production function.

What is the most likely scenario empirically? Most empirical estimates conclude that output per capita is increasing in the initial level of multifactor productivity, its growth, and physical and capital investment rates. Higher initial levels of multifactor productivity increases output per capita and the higher the growth rate of multifactor the higher the output per capita, as well. Higher investment rates increase the levels of physical and human capital per capita, which then increases output per capita. Output per capita, however, is decreasing in capital per capita depreciation. But we do not have any a priori expectation about the sign on the coefficient of corruption.

\section{The Data, Modeling and Estimation Strategy}

In this section we formulate an economic growth model - based on analytical framework outlined above- to capture the causal mechanisms and transmission channels in the corruption-growth relationship. We use the growth model introduced by [26], the model regresses output on investment, human capital, and a number of other variables such as openness to trade, government expenditure variables and political stability. Formally, the base model can be stated as follows:

$$
\begin{gathered}
\ln y=\alpha+\beta_{k} \ln z+\mu, \\
z=(i, h, g, x, s)
\end{gathered}
$$

where $y$ is the natural $\log$ of real GDP per capita, and $z$ is the $k \times 1$ vector of control variables that are de- 
rived from the growth theory or are expected to influence growth such as (investment $(i)$, human capital $(h)$, government expenditure $(g)$, openness to trade $(x)$ and political instability $(s)), \mu$ is the error term and the parameters to be estimated are $\alpha, \gamma$, and $\beta{ }^{1}$

Then, we will add the corruption variable to the base model and estimate again the following equation:

$$
\ln y=\alpha+\gamma_{1} \ln c+\beta_{k} \ln z+\mu,
$$

where $c$ is the corruption index. Comparing the results of estimating Equations (6) and (8) will capture the effect of corruption on economic growth and also provide support as to whether or not corruption impacts other explanatory variables in the economic growth model. To obtain consistent estimates, we use log-linear specification for our empirical purpose. The advantages of this system are well known. It gives a controlling for the initial income level and/or for other economic variables. On another hand, this model might be facing a problem when estimated because the explanatory variables (e.g. corruption) may themselves be affected by the dependent variable (i.e. growth). If endogeneity exists and is not addressed, reported estimates are likely to be biased upward due to reverse causality. To overcome this problem, we used past values of endogenous regressors and current values of strictly exogenous regressors as instruments. This method has been suggested by [27] and has been used extensively in the growth literature. It is known as the General Method of Moments (GMM) estimation, which exploits the linear moment restrictions of the model. It has been shown to be an efficient method of instrumentation when there is not sufficient instrumentation data for the endogenous variables. The model specified above will be estimated using time series data on Egyptian economy. The paper used annual data from 1990 to 2012 gathered from the International Monetary Fund's, International Financial Statistics, International Financial Statistics (IFS) 2013 CD-ROM, World Development Indicators (WDI) 2013 CD-ROM and Central Bank of Egypt (various reports). We used the education and health expenditure as a proxy of human capital and the data on Corruption Perceptions Index (CPI) has collected from Transparency International (various reports). This index ranges from zero to six, with higher scores indicating lower corruption levels. To measure political instability (PI), we employ the political stability index drawn from Kaufman, Kraay and Mastruzzi [28] over the period 1996-2002. This index has been transformed on a scale that ranges between zero and five so that higher levels correspond to more political instability instead of less as on the original scale.

In order to estimate the model-especially when working with the time series data, the series that belong to variables should be stationary. Therefore; it is necessary to make test for unit roots to examine whether the series for these two variables are stationary or not.

To overcome this problem, the first step of this study was to examine the stationary of the variables. If all the variables are stationary $I(0)$, then there is no problem to estimate the coefficients using the variables with initial specification. ${ }^{2}$ Most commonly used test for the integration order of variables is Augmented Dickey-Fuller test [29]. This test is described by the following equations:

$$
\text { (ADF) } \Delta H=k+\varphi_{i} H_{t-1}+\sum_{i=1}^{n} \varphi_{i} \Delta H_{t-1}+\varepsilon_{t}
$$

where $H$ is the variable under consideration, $\Delta$ is the first difference operator, $t$ captures any time trend, $\varepsilon_{t}$ is a random error, and $\mathrm{n}$ is the maximum lag length. The optimal lag length is identified so as to ensure that the error term is white noise. If we cannot reject the null hypothesis $\varphi=0$ then we conclude that the series under consideration has a unit root and is therefore non-stationary.

The results from the Augmented Dickey-Fuller test in Table 1 indicate that the null hypothesis of a unit root in the time series cannot be rejected at a $5 \%$ level of significance in variable levels. Therefore, no time series appear to be stationary in variable levels. Thus, the evidence presented suggests that the variables in question follow primarily a stochastic trend as opposed to a deterministic one, although the possibility that for given sub periods they follow a mixed process cannot be rejected. However, when the logarithms of the time series are transformed into their first differences, they become stationary and consequently the related variables can be characterized integrated of order one, $I(1)$.

\footnotetext{
${ }^{1} \beta_{k}$ the vector of coefficients represents the partial effects of the control variables on growth.

${ }^{2}$ Most of the main macroeconomic variables are non-stationary, integrated of order higher than zero. If the series are non-stationary but cointegrated, then the estimation as an autocorrected model is admissible. If the variables are non-stationary and are not co-integrated then the specification of variables as differences is necessary.
} 
Table 1. Unit root test result.

\begin{tabular}{ccc}
\hline \multirow{2}{*}{ Variable } & \multicolumn{2}{c}{ ADF } \\
\cline { 2 - 3 } & Level & First Difference \\
\hline Lny & -2.54314 & $-6.35070^{*}$ \\
Ln $i$ & -0.88105 & $-9.6493^{*}$ \\
Lng & -1.6792 & $-7.9251^{*}$ \\
Ln $h$ & -2.5638 & $-6.9856^{*}$ \\
Ln $x$ & -1.7692 & $-8.6591^{*}$ \\
Ln $p$ & -2.9830 & $-5.7628^{*}$ \\
Lnc & -1.6040 & $-7.9823^{*}$ \\
\hline$* * *$, and $^{* * *}$ indicate significance at $1 \%, 5 \%$ and $10 \%$ levels respectively.
\end{tabular}

The next step to find the impact of corruption and other explanatory variables on economic growth is estimated Equations (6) and (8), using the GMM estimator. The results of this estimation reported in Table 2.

Table 2 reports the estimate Equation (6) of the baseline model as well as the statistical tests we performed. These results suggest that the impact of foreign direct investment, government expenditure and human capital are positive and statistically (and economically) significant at the 5 percent level in the growth rate in real GDP, while openness and political instability have a negative impact on economic growth rate. These results are in line with previous empirical literature on the determinants of economic growth that have supported a positive effect of investment, government expenditure and human capital on growth and, on the other hand, a negative impact of openness and political instability especially in developing countries. According to estimate results of Equation (8) as reported in Table 2, we found that the corruption coefficient had negative effect on economic growth but not statically significant. On the other hand, when the corruption variable entitled in the model, the magnitude of the investment, government expenditure and human capital coefficients are reduced, suggesting that corruption as we introduced corruption to the base model. This means that due to corruption, the effectiveness of investment, government expenditure and human capital are reduced. This explains effect of the corruption on these variables.

While the base Equation (6) is able to measure the direct impact of corruption on economic growth, in line with [30] certain adjustments are made to Equation (8) to capture the impact of corruption on five determinants of economic growth at once, namely investment, human capital, government expenditure, openness and political instability. These variables resume most of the transmission channels explored by previous empirical studies [31] [32]. The choice of these transmission variables is also consistent with the existing empirical literature that acknowledges their role as major determinants of economic growth while showing that each of which is significantly affected by corruption. Indeed, numerous studies have found that corruption has significant impact on investment, on human, on government, on openness [33] [34].

Now consider Equation (7). The indirect effect of corruption on economic growth via the pervious transmission variables can represent by the following equations:

$$
\begin{aligned}
& \ln y=\alpha+\gamma_{1} \ln c+\beta_{k} \ln z+\delta \ln (c * i)+\mu, \\
& \ln y=\alpha+\gamma_{1} \ln c+\beta_{k} \ln z+\delta \ln (c * g)+\mu, \\
& \ln y=\alpha+\gamma_{1} \ln c+\beta_{k} \ln z+\delta \ln (c * x)+\mu, \\
& \ln y=\alpha+\gamma_{1} \ln c+\beta_{k} \ln z+\delta \ln (c * h)+\mu, \\
& \ln y=\alpha+\gamma_{1} \ln c+\beta_{k} \ln z+\delta \ln (c * p)+\mu,
\end{aligned}
$$

Based on [35] empirical framework, we apply Egyptian's time series data to estimate each of Equations (9)(13). Table 3 shows the main results from the regressions which correspond to Equations (9) to (13), and in each regression a constant term and a random stochastic disturbance term with usually assumed properties are included. 
Table 2. Result of regression equations.

\begin{tabular}{ccc}
\hline Explanatory Variables & Equation (6) & Equation (8) \\
\hline Constant & $2.56(2.15)^{*}$ & $2.83(2.09)^{*}$ \\
Ln $i$ & $0.39(2.86)^{* *}$ & $0.16(2.11)^{*}$ \\
Ln $h$ & $1.37(3.29)^{* * *}$ & $0.46(2.92)^{* *}$ \\
Lng & $2.28(3.61)^{* * *}$ & $1.78(3.01)^{* * *}$ \\
Ln $x$ & $-1.25(-2.13)^{*}$ & $-3.45(-2.89)^{* *}$ \\
Lnp & $-4.73(-2.65)^{* *}$ & $-4.89(-3.42)^{* * *}$ \\
Lnc & $\mathrm{NA}$ & $-1.3(-1.51)$ \\
$R$-square & 0.61 & 0.68 \\
Adjusted $R$-square & 0.57 & 0.63 \\
Durbin-Watson & 0.481 & 0.538 \\
\hline
\end{tabular}

Notes: t-statistics in parentheses; dependent variable: ${ }^{* * *}$ statistically significant at the $1 \%$ level; ${ }^{* *}$ statistically significant at the $5 \%$ level; ${ }^{*}$ statistically significant at the $10 \%$.

Table 3. Result of regression equations.

\begin{tabular}{|c|c|c|c|c|c|}
\hline \multirow{2}{*}{ Explanatory Variables } & Equation (9) & Equation (10) & Equation (11) & Equation (12) & Equation (13) \\
\hline & $Y_{t}$ & $Y_{t}$ & $Y_{t}$ & $Y_{t}$ & $Y_{t}$ \\
\hline Constant & $16.48(-3.11)^{* * *}$ & $-40.53(-3.06)^{* * *}$ & $-45.86(-3.78)^{* * *}$ & $-38.76(-2.65)^{* *}$ & $-41.29(-4.81)^{* * *}$ \\
\hline $\operatorname{Ln} i$ & $0.286(2.21)^{* *}$ & $0.405(3.06)^{* * *}$ & $0.41(3.71)^{* * *}$ & $0.39(3.24)^{* * *}$ & $0.35(2.98)^{* *}$ \\
\hline Lng & $0.42(3.28)^{* * *}$ & $0.28(2.86)^{* *}$ & $0.37(2.67)^{* *}$ & $0.36(2.41)^{* *}$ & $0.34(2.39)^{* *}$ \\
\hline $\operatorname{Ln} h$ & $0.26(2.48)^{* *}$ & $0.24(3.56)^{* * *}$ & $0.19(1.52)$ & $0.31(2.27)^{* *}$ & $0.29(2.96)^{* *}$ \\
\hline $\operatorname{Ln} x$ & $-0.41(2.61)^{* *}$ & $-0.48(-2.99)^{* *}$ & $-0.39(-2.76)^{* *}$ & $-0.37(-2.16)^{*}$ & $-0.43(-2.74)^{* *}$ \\
\hline $\operatorname{Ln} p$ & $-0.007(-2.08)^{*}$ & $-0.003(-2.19)^{*}$ & $-0.001(-2.48)^{* *}$ & $-0.006(-2.39)^{* *}$ & $-0.018(-2.13)^{*}$ \\
\hline $\operatorname{Ln} c$ & $-2.69(-3.04)^{* * *}$ & $-1.84(2.39)^{* *}$ & $-0.45(-1.16)$ & $-1.37(-2.02)^{*}$ & $-2.58(-2.74)^{* *}$ \\
\hline$c * i$ & $-0.02(-2.56)^{*}$ & & & & \\
\hline$c * g$ & & $0.03(0.27)$ & & & \\
\hline$c * h$ & & & $-0.08(-0.73)$ & & \\
\hline$c * x$ & & & & $-2.33(-3.42)^{* * *}$ & \\
\hline$c * p$ & & & & & $-2.48(-2.57)^{* *}$ \\
\hline Adj. $R$-sq. & 0.643 & 0.715 & 0.694 & 0.741 & 0.709 \\
\hline Serial correlation & 0.054 & 0.047 & 0.027 & 0.297 & 0.093 \\
\hline Heteroscedasticity & 0.381 & 0.463 & 0.293 & 0.692 & 0.471 \\
\hline
\end{tabular}

Notes: with t-statistics in parentheses; ${ }^{* * *}$ statistically significant at the $1 \%$ level; ${ }^{* *}$ statistically significant at the $5 \%$ level; ${ }^{*}$ statistically significant at the $10 \%$; results of diagnostic tests are shown as $p$-values.

According to the results from Table 3, when the interaction term between corruption and other explanatory variables mentioned in the model, the corruption has a negative impact on economic growth through the investment, human capital, openness and political stability and still have positive effect on economic growth through the government expenditure but not statically significant. This means that the model predicts that indirect effects will enhance the decreasing effect of economic growth through both government expenditure and corruption. ${ }^{3}$

${ }^{3}$ This is results is consistent with traditional argument that corruption reduce the economic growth through the government expenditure is valid. 
From the results, it can be seen that corruption creates inefficiencies and reduces the potential effect of investment in the Egyptian economy; as the coefficient of foreign direct investment is positive but the coefficient of the interaction term between foreign direct investment and corruption is negative. Precisely, a unit rise in corruption reduces the effect of foreign direct investment on economic output per worker by about $2 \%$, while the indirect effect of corruption on economic output via foreign direct investment may be statistically insignificant; however, it is in consonance with general economic belief. This mean that if investors were to choose between two countries with different levels of corruption, they may choose not to start their business in a more corrupt country since the profit in that country will be reduced.

Similarly, these results also show that with the introduction of an interaction term between human capital, openness and political instability the presence of corruption brings about a negative response of economic output to the effect of human capital, openness and political instability over time. Thus, implying a one point increase in the corruption index decreases growth by $0.13 \%$ via the human capital channel, by $0.23 \%$ via the openness channel, and, by $0.25 \%$ via the political instability channel. The results suggest that only the openness, human capital and political instability channels involve statistically significant effects at the conventional levels. Taken together, openness, human capital and political instability describe almost $70 \%$ of the total negative impact of corruption on growth. On the other hand, the results of Equation (9) estimation suggested that with the introduction of the interaction term between government expenditure and corruption, government expenditure still bring about a positive effect on the economic growth but at a reduced rate, thus implying corruption corrodes the government expenditure in Egypt.

The results reported above suggest that human capital, openness and political instability are the most important transmission variables through which corruption is likely to reduce growth. However, there is no evidence that foreign direct investment constitutes a significant transmission channel via which corruption operates and the government expenditures effect is much reduced and becomes statistically insignificant.

According to the all data regressions in Table 1 to Table 3 together suggest that no significant direct effect from corruption on growth was found. The indirect effect of corruption on growth was also tested. The only significant finding was the interaction effect, with investment, Openness, and political instability. Corruption was found to cause the effect of investment on the growth rate to decrease. One interesting explanation for the negative effect on the growth rate can be that the wrong types of investments are made because of the possibility to hide corruption in their excessive budgets. The results show that the effect of interaction effect, with Openness is negative and statistically significant. This finding is consistent with the line of literature that are argued that as import and trade restrictions create incentives for rent seeking activities, corruption may increase. This is due to the point, that even though lobbyism may be used in order to obtain the economic rents, associated with imposed tariffs, bribes may be used whenever lobbyism does not prove effective. [35] argues in line with this. Finally, the results also conclude that the interaction between corruption and political stability has significant and negative affect on economic growth. One explanation of that is a deficiency in the political system increase corruption. In addition, they state that an established democracy can, through political competition, increase transparency and accountability, which in turn lowers corruption. This conclusion is supported by [36], who maintain, that weaker government effectiveness, leads to a higher level of corruption. In addition they argue that promoting political competition and increasing transparency and accountability reduces the scope of corruption.

\section{Concluding Remarks}

This paper employs an empirical methodology to investigate the direct and indirect impact of corruption on economic growth in Egypt over the period 1990-2012. By estimating an extended endogenous growth model that allows for this effect in which corruption is allowed to influence a number of growth determining variables, we are able to perform precise inference concerning the channels of influence from corruption to growth. There are three benefits from this approach. Firstly, direct links between corruption and growth follow clearly from the literature, whereas an indirect effect of corruption on growth is not theoretically and empirically well grounded. Secondly, we are able to observe an additional effect: the impact of the effect of corruption on growth through the main determinants of Economic growth. Lastly, we quantify the magnitude of the various effects of corruption through the channels which are most important for growth. This may help design anti-corruption policies that maximize the benefits of democracy while minimize its costs.

Our results show that that the overall effect of corruption on growth is negative and moderate, confirming re- 
sults from previous studies. However, our methodology allows us to go beyond previous research and describe what drives this overall result: We find evidence that the interaction between corruption and foreign direct investment (FDI), human capital, openness and political stability has a negative impact on economic growth in Egypt. In addition, the interaction between corruption and government expenditure lowers the economic growth in Egypt by reducing the effectiveness of government expenditure on economic growth. Finally, when we sum up the effects of corruption on growth, the negative effect through openness, human capital and political instability are dominated. These channels are almost describing $70 \%$ of the total negative impact of corruption on growth in Egypt.

While the result imply that direct and indirect negative association between corruption and economic growth, the question of how to design anti-corruption policies to enhance the economic growth in Egypt is beyond the scope of the current analysis, and emerges as an interesting avenue for further research.

\section{References}

[1] Rose-Ackerman, S. (1975) The Economics of Corruption. Journal of Public Economics, 4, 187-203. http://dx.doi.org/10.1016/0047-2727(75)90017-1

[2] Mauro, P. (1995) Corruption and Growth. Quarterly Journal of Economics, 110, 681-712. http://dx.doi.org/10.2307/2946696

[3] Bardhan, P. (1997) Corruption and Development: A Review of Issues. Journal of Economic Literature, 35, $1320-1346$.

[4] World Bank (1997) World Development Report: The State in a Changing World. Oxford University Press, New York.

[5] Mo, P.H. (2001) Corruption and Economic Growth. Journal of Comparative Economics, 29, 66-79. http://dx.doi.org/10.1006/jcec.2000.1703

[6] Dreher, A. and Herzfeld, T. (2005) The Economic Costs of Corruption: A Survey and New Evidence. Working Paper 0506001, Public Economics, EconWPA.

[7] Pellegrini, L. (2011) Chapter 4: The Effect of Corruption on Growth and Its Transmission Channels. In: Pellegrini, L., Ed., Corruption, Development and the Environment, Springer, Berlin, 53-74.

[8] Gyimah-Brempong, K. (2002) Corruption, Economic Growth and Income Inequality in Africa. Economics of Governance, 3, 183-209. http://dx.doi.org/10.1007/s101010200045

[9] Li, H., Xu, L.C. and Zou, H. (2000) Corruption, Income Distribution and Growth. Economics \& Politics, 12, $155-182$. http://dx.doi.org/10.1111/1468-0343.00073

[10] Tanzi, V. and Davoodi, H.R. (1997) Corruption, Public Investment and Growth. Working Paper of the International Monetary Fund, Fiscal Affairs Department, WP/ 97/139.

[11] Wei, S.-J. (2000) How Taxing Is Corruption on International Investors. The Review of Economics and Statistics, 82, 111. http://dx.doi.org/10.1162/003465300558533

[12] Wei, S.-J. (2000) Local Corruption and Global Capital Flows. Brooking Papers on Economic Activity, 31, 303-354. http://dx.doi.org/10.1353/eca.2000.0021

[13] Drabek, Z. and Payne, W. (2001) The Impact of Transparency on Foreign Direct Investment. Staff Working Paper ERAD-99-02, World Trade Organization, Geneva.

[14] Habib, M. and Zurawicki, L. (2002) Corruption and Foreign Direct Investment. Journal of International Business Studies, 33, 291-307. http://dx.doi.org/10.1057/palgrave.jibs.8491017

[15] Javorcik, B.S. and Wei, S.-J. (2009) Corruption and Cross-Border Investment in Emerging Markets: Firm-Level Evidence. Journal of International Money and Finance, 28, 605-624. http://dx.doi.org/10.1057/palgrave.jibs.8491017

[16] Busse, M. and Hefeker, C. (2007) Political Risk, Institutions and Foreign Direct Investment. European Journal Political Economy, 23, 397-415. http://dx.doi.org/10.1016/j.ejpoleco.2006.02.003

[17] Hakkala, K.N., Norback, P. and Svaleryd, H. (2008) Asymmetric Effects of Corruption on FDI: Evidence from Swedish Multinational Firms. The Review of Economics and Statistics, 90, 627-642. http://dx.doi.org/10.1016/j.ejpoleco.2006.02.003

[18] Blackburn, K., Bose, N. and Haque, E.M. (2006) The Incidence and Persistence of Corruption in Economic Development. Journal of Economic Dynamics and Control, 30, 2447-2467. http://dx.doi.org/10.1016/j.jedc.2005.07.007

[19] Blackburn, K. and Forgues-Puccio, G.F. (2007) Distribution and Development in a Model of Misgovernance. European Economic Review, 51, 1534-1563. http://dx.doi.org/10.1016/j.euroecorev.2006.10.003

[20] Gupta, S., Davoodi, H. and Tiongson, E. (2000) Corruption and the Provision of Health Care and Education Services. IMF Working Paper No. 00/116. 
[21] Reinikka, R. and Svensson, J. (2005) Fighting Corruption to Improve Schooling, Evidence from a Newspaper Campaign in Uganda. Journal of European Economic Associations, 3, 259-267. http://dx.doi.org/10.1162/jeea.2005.3.2-3.259

[22] Mo, P.H. (2001) Corruption and Economic Growth. Journal of Comparative Economics, 29, 66-79. http://dx.doi.org/10.1162/jeea.2005.3.2-3.259

[23] Pellegrini, L. (2011) The Effect of Corruption on Growth and Its Transmission Channels. In: Pellegrini, L., Ed., Corruption, Development and the Environment, Springer, Berlin, 53-74.

[24] Mankiw, N.G., Romer, D. and Weil, D. (1992) A Contribution to the Empirics of Economic Growth. Quarterly Journal of Economics, 107, 407-437. http://dx.doi.org/10.2307/2118477

[25] Schleifer, A. and Vishny, R.W. (1993) Corruption. The Quarterly Journal of Economics, 108, 599-617. http://dx.doi.org/10.2307/2118402

[26] Barro, R.J. (1991) Economic Growth in a Cross Section of Countries. Quarterly Journal of Economics, 106, $407-443$.

[27] Arellano, M. and Bond, S. (1991) Some Tests of Specification for Panel Data: Monte Carlo Evidence and an Application to Employment Equations. The Review of Economic Studies, 58, 277-297.

[28] Kaufmann, D., Kraay, A. and Mastruzzi, M. (2008) Governance Matters VII: Aggregate and Individual Governance Indicators, 1996-2007. The World Bank, Policy Research Working Paper Series No. 4654.

[29] Dickey, D.A. and Fuller, W.A. (1979) Distribution of the Estimators for Autoregressive Time Series with a Unit Root. Journal of the American Statistical Association, 74, 427-431.

[30] Dzhumashev, R. (2009) Is There a Direct Effect of Corruption on Growth? Munich Personal RePEc Archive, MPRA Paper No. 18489, 1-16. http://mpra.ub.uni-muenchen.de/18489/

[31] Dreher, A. and Herzfeld, T. (2005) The Economic Costs of Corruption: A Survey and New Evidence. Working Paper 0506001, Public Economics, Econ WPA.

[32] Dreher, A., Kotsogiannis, C. and McCorriston, S. (2007) Corruption around the World: Evidence from a Structural Model. Journal of Comparative Economics, 35, 443-466. http://dx.doi.org/10.1016/j.jce.2007.07.001

[33] Mauro, P. (1995) Corruption and Growth. Quarterly Journal of Economics, 110, 681-712. http://dx.doi.org/10.2307/2946696

[34] Rajkumar, A.S. and Swaroop, V. (2008) Public Spending and Outcomes: Does Governance Matter? Journal of Development Economics, 86, 96-111. http://dx.doi.org/10.1016/j.jdeveco.2007.08.003

[35] Al-Marhubi, F.A. (2000) Corruption and Inflation. Economics Letters, 66, 199-202. http://dx.doi.org/10.1016/S0165-1765(99)00230-X

[36] Buehn, A. and Schneider, F. (2012) Shadow Economies around the World: Novel Insights, Accepted Knowledge and New Estimates. International Tax and Public Finance, 19, 139-171. http://dx.doi.org/10.1007/s10797-011-9187-7 
Scientific Research Publishing (SCIRP) is one of the largest Open Access journal publishers. It is currently publishing more than 200 open access, online, peer-reviewed journals covering a wide range of academic disciplines. SCIRP serves the worldwide academic communities and contributes to the progress and application of science with its publication.

Other selected journals from SCIRP are listed as below. Submit your manuscript to us via either submit@scirp.org or Online Submission Portal.
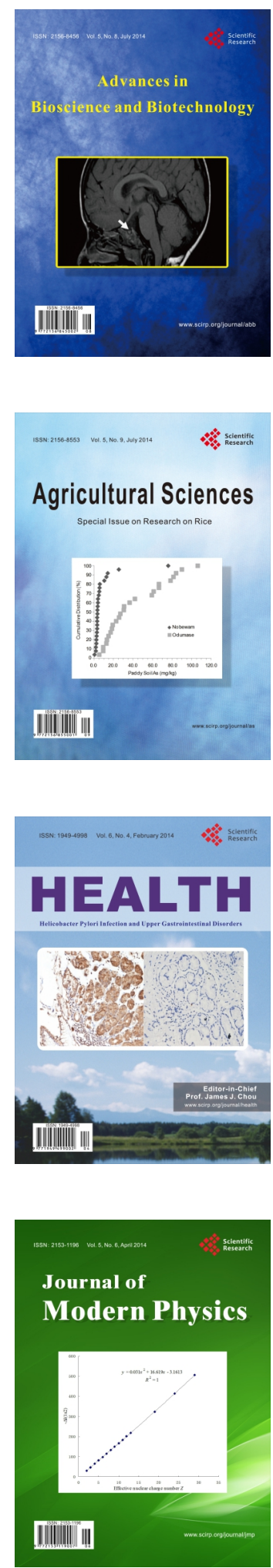
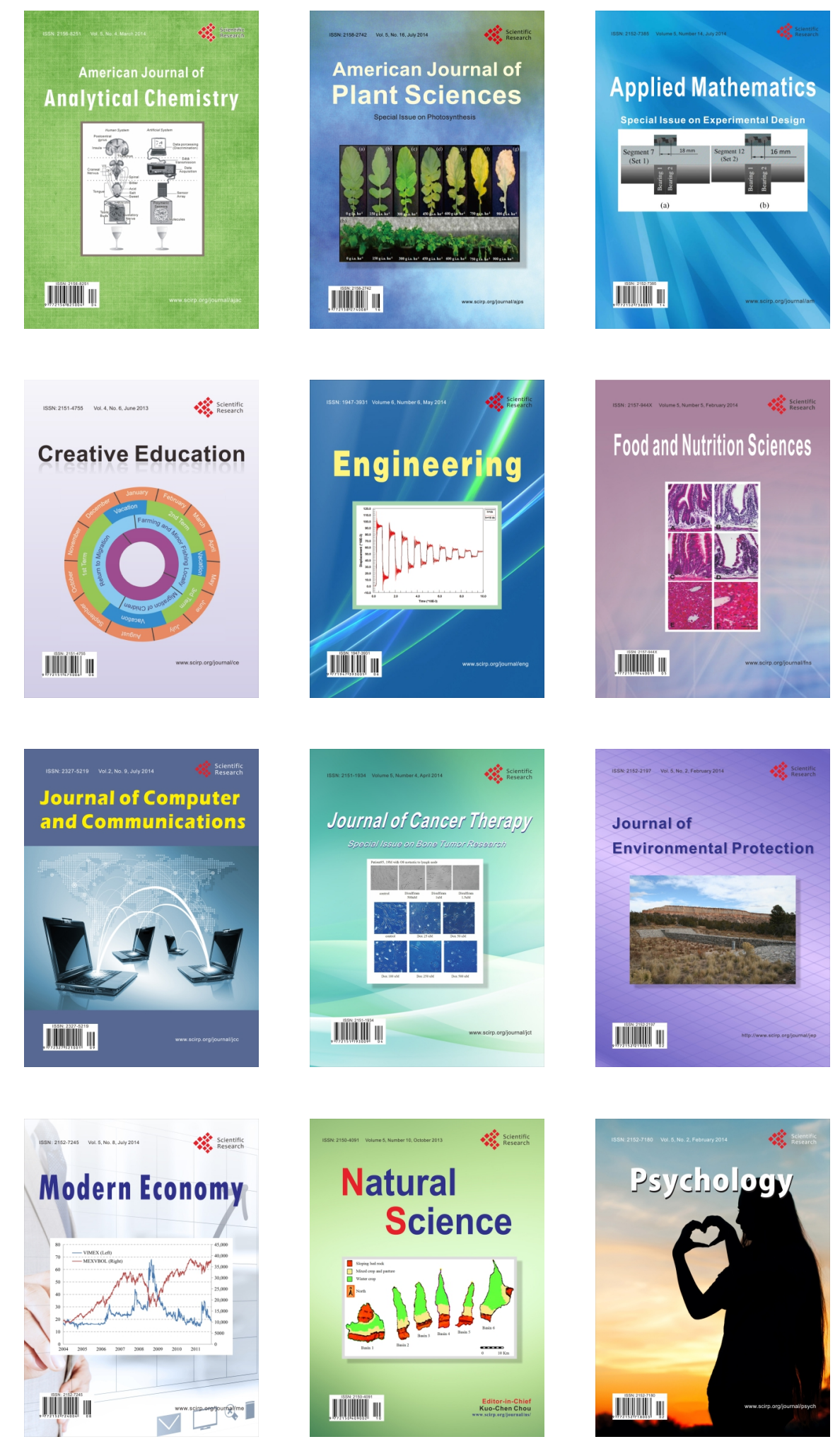